\title{
GENETIC ASPECTS OF BILIARY ATRESIA ETIOLOGY
}

Isaeva MKh ${ }^{\circledR}$, Belova VA², Korostin $\mathrm{DO}^{2}$, Degtyareva $\mathrm{AV}^{1,3}$

${ }^{1}$ National Medical Research Center for Obstetrics, Gynecology and Perinatology named after Academician V. I. Kulakov, Moscow, Russia

2 Pirogov Russian National Research Medical University, Moscow, Russia

${ }^{3}$ Sechenov University, Moscow, Russia

Biliary atresia $(B A)$ is a cholestatic disorder of infancy that is fatal if untreated. Despite years of study the etiology of BA remains unknown. Three etiopathogenic mechanisms may be involved, such as immune dysregulation, environmental factors and genetic susceptibility. Genetic predisposition is being actively studied. Candidate genes associated with BA in certain populations, genes affecting the cholangiocyte cilia function, as well as genes involved in stress responses have been identified. However, the long-term follow-up of twins with BA suggests that genotype is not of paramount importance for the disease development. Both epigenetic patterns and postzygotic somatic mutations may contribute to etiology of the disease. Recently, some evidence is being accumulated on the possible genetic predisposition to certain outcome of Kasai portoenterostomy performed in patients with BA. However, the presence of a number of factors contributing to the development of the disease makes it difficult to identify the genetic markers.

Keywords: biliary atresia, biliary atresia etiology, cholestasis, liver disease, genetic factors

Funding: the study was supported by grant № 075-15-2019-1789 of the Ministry of Science and Higher Education of the Russian Federation issued to ensure state support for the Center for Precision Genome Editing and Genetic Technologies for Biomedicine.

Author contribution: Isaeva MKh, Belova VA — literature analysis, manuscript writing; Korostin DO, Degtyareva AV — concept and structure of the review, manuscript editing.

$\triangle$ Correspondence should be addressed: Medan Kh. Isaeva

Oparina, 4B, Moscow, 117513; medan.isayeva@bk.ru

Received: 08.10.2020 Accepted: 24.10.2020 Published online: 06.11.2020

DOI: $10.24075 /$ brsmu.2020.069

\section{ГЕНЕТИЧЕСКИЕ АСПЕКТЫ ЭТИОЛОГИИ БИЛИАРНОЙ АТРЕЗИИ}

\author{
М. Х. Исаева ${ }^{1}$, В. А. Белова², Д. О. Коростин², А. В. Дегтярева ${ }^{1,3}$
}

${ }^{1}$ Национальный медицинский исследовательский центр акушерства, гинекологии и перинатологии имени академика В. И. Кулакова, Москва, Россия

2 Российский национальный исследовательский медицинский университет имени Н. И. Пирогова, Москва, Россия

${ }^{3}$ Первый Московский государственный медицинский университет имени И. М. Сеченова, Москва, Россия

\begin{abstract}
Билиарная атрезия (БА) - это холестатическое заболевание печени, которое дебютирует в младенческом возрасте и при отсутствии своевременного лечения приводит к циррозу печени с прогрессирующей печеночной недостаточностью. Несмотря на многолетние исследования, этиология билиарной атрезии остается не до конца изученной. Среди факторов, вовлеченных в этиопатогенез БА, выделяют иммунную дисрегуляцию, факторы окружающей среды и генетическую предрасположенность. Роль генотипа пациента в развитии заболевания активно изучается, выявлены гены-кандидаты, ассоциированные с БА в определенных популяциях, гены, влияющие на функционирование ресничек холангиоцитов, а также гены, участвующие в стресс-реакциях. Однако, исходя из многолетних результатов наблюдений близнецов с БА, можно сделать вывод о том, что роль генотипа не является первостепенной в развитии заболевания. Предположительно, в этиологию заболевания могут вносить вклад как эпигенетические механизмы, так и постзиготические соматические мутации. В последнее время накапливаются также данные о возможной генетической предрасположенности к исходу портоэнтеростомии по Касаи, проводимой при БА. Вместе с тем, наличие многих факторов, играющих роль в развитии заболевания, создает трудности в выявлении точных генетических маркеров.
\end{abstract}

Ключевые слова: билиарная атрезия, этиология билиарной атрезии, холестаз, заболевание печени, генетические факторы

Финансирование: работа была поддержана грантом №075-15-2019-1789 Министерства образования и науки РФ, выделенным на осуществление государственной поддержки создания и развития «Центра высокоточного редактирования и генетических технологий для биомедицины».

Вклад авторов: М. Х. Исаева, В. А. Белова - изучение литературы, написание обзора; Д. О. Коростин, А. В. Дегтяева - вклад в концепцию и структуру обзора, редактирование.

$\triangle$ Для корреспонденции: Медан Хасановна Исаева

ул. Академика Опарина, д. 4Б, г. Москва, 117513; medan.isayeva@bk.ru

Статья получена: 08.10.2020 Статья принята к печати: 24.10.2020 Опубликована онлайн: 06.11.2020

DOI: $10.24075 /$ vrgmu.2020.069

Biliary atresia $(B A)$ is an inflammatory fibrosing obliteration of the extrahepatic biliary tree gradually involving the intrahepatic biliary system and leading to cirrhosis. The isolated (nonsyndromic) forms of the disease are more common (85\% of cases) compared to syndromic (embryonal, 10-15\% of cases) and cystic forms (5-8\% of cases). The incidence of $B A$ varies across countries from $1: 8,000$ (Asia and Africa) to 1 : 18,000 (Europe), and more common for female infants [1, 2]. The clinical presentation of the disease is neonatal cholestasis.
However, the differential diagnosis is carried out with a large group of congenital and hereditary disorders, many of which have manifestations similar to BA during the first months of life $[3,4]$. The diagnosis is confirmed by morphological examination of liver and bile duct biopsies during surgery. Surgical correction (Kasai portoenterostomy, KPE) and liver transplantation make it possible the overall infants survival with BA to 90\% [4-6]. However, the causes of BA, as well as factors determining the treatment outcome remain poorly understood. 


\section{Etiology of the disorder}

Prior to becoming familiar with genetic patterns associated with BA and contributing to the treatment outcome, the other factors involved in the BA pathogenesis should be mentioned briefly: immune dysregulation and environmental factors (viruses, toxins).

There is a lot of data on etiological factors, among which the immune dysregulation plays an essential role. BA is a fibro-inflammatory disease characterized by presence of inflammatory cell infiltration and cytokines and/or chemokines overexpression in patients' liver biopsies. The key element in the BA immunopathogenesis is the innate immune response involving activation of NK cells and Th1 cells subpopulation, also known as Th1 adaptive immune response involving the effector $\mathrm{T}$ cells, which results in inflammation and obstruction [7]. At the same time, there is a decrease in the number of Treg cells, which are able to suppress inflammation. After the onset of obstruction the immune-mediated bile duct damage persists due to activation of Th2 and Th17 responses regardless of the bile outflow restoration [8]. However, no post-transplant disease recurrence is observed, in contrast to other immunemediated bile duct diseases [9].

The viral or toxic effect on the bile duct epithelium is likely to give rise to new epitopes contributing to initiation and exacerbation of autoimmune inflammation [8, 10]. The following pathogenic viruses are considered: CMV, HBV, human herpesvirus 6, EBV, reovirus and rotavirus [11]. Numerous studies using the PCR technique (detection of viral DNA/RNA) or viral $\operatorname{lgM}^{+}$and $\mathrm{Mx}$ protein immunostaining revealed traces of viral infection in some, but not all, liver tissue specimen $[12,13]$. Currently, there is no clear evidence of BA resulting from viral infection due to inconsistent results of studies using no reference samples, methodological inaccuracies and ambiguous data interpretation [10, 11, 14]. Paradoxically, BA does not affect adults infected with these viruses. But viral infection aggravates the course of BA and increases the risk of adverse outcome [12, 13, 15].

Of exogenous toxins able to trigger the outbreak of BA in animals, the previously undescribed isoflavonoid biliatresone was isolated in Australia from plants consumed by livestock during the drought [16]. In zebrafish (Danio rerio) larvae, being a common animal model, biliatresone induces the damage to extrahepatic, but not to intrahepatic bile ducts [17]. Despite the fact that humans are not exposed to biliatresone, recognition of bile ducts damage patterns may contribute to uncovering toxins capable of affecting humans.

\section{Genetic factors and BA}

In contemporary literature more data on the patients' genetic susceptibility to BA becomes available. The inheritance of biliary atresia is not Mendelian. As a result, the disorder is not inherited, although several such cases have been reported [18]. High incidence of BA in parts of Asia suggests the greater distribution of genetic variants associated with BA in these populations. However, the environmental factors (nutritional status, viral load, etc.), as well as the differences in diagnostic criteria used by Asian specialists should also be considered [19].

\section{Twins with BA}

Genes that are likely to be involved in biliary atresia are discussed below. The intriguing results of meta-analysis reported in 2020 are worth noting: the authors reviewed the previously reported global cases of twins with BA and discovered that among 35 prominent pairs (19 monozygotic, 15 dizygotic, and one undefined) only one pair (dizygotic) demonstrated concordance for $\mathrm{BA}$, and the other pairs were discordant, i. e. only one twin out of two was diagnosed with BA (97.1\%) [20]. A retrospective study performed by Chinese researchers also reported 19 twin sets with BA, all of them demonstrated discordance for BA (8 were monozygotic and 11 were dizygotic) [21].

The twins' discordance for BA suggests that hereditary factors are not of paramount importance for the disease development, since monozygotic twins possess the same genotype. Meanwhile, contamination by infectious or toxic agent should rather have affected both twins in utero leading to the development of the disease. Among all reported cases of toxic or infectious embryopathy, the twins' concordance (especially monozygotic) is about $80 \%$ [22]. It is known that in addition to gene nucleotide sequence alterations, the epigenetic modifications possessing nonclassic genetic inheritance pattern may affect the phenotype. Thus, the monozygotic discordant twins with BA had different phenotypes, which increased the likelihood of the epigenetic factors contribution to the BA pathogenesis [20].

The post zygotic somatic pathogenic variant may also occur in one of the twins, within genes, regulatory regions, etc. being the potential triggers of obliterative cholangiopathy. The hypothesis about BA resulting from somatic mutation (it is better to use the term "pathogenic variant") was proposed in 2016. The authors suggest to analyze DNA from liver tissue and biliary tract of the patients, as well as to perform analysis of parental genomes in order to justify the hypothesis [22].

\section{Candidate genes}

Genetic approaches to BA include the analysis of candidate genes, CNV (copy number variation), genome-wide association studies (GWAS), and whole exome sequencing (WES). GWAS are focused on evaluation of associations between the disorder and the common genetic variants in various populations of the treatment group of patients and the control group of healthy individuals. The table presents some candidate genes associated with BA identified in a number of GWAS.

\section{Genes GPC1 and AGXT}

During one of the GWAS, in two of 35 unrelated children with verified BA (2,026 healthy individuals served as controls) the heterozygous deletion of 2 q37.3 was identified [23]. The overlapping deletion (1.76 Mb) contained 30 genes, of which the authors selected the candidate gene AGXT expressed in liver. Alanine-glyoxylate aminotransferase (AGXT), the hepatic peroxisomal enzyme involved in metabolism of toxic substances and lipid cleavage, is encoded by this gene. It can be assumed that the reduced activity of AGXT involved in detoxication is essential under the context of the toxin-mediated damage to biliary tract involvement in the pathogenesis of BA. The authors presented a detailed description of patients carrying a deletion 2q37.3. In the first case, the woman worked for a house cleaning service and was often exposed to potentially toxic cleaning agents during pregnancy. In the second case, the woman had a varicella infection at 15 weeks gestation, and was treated with acyclovir, which crossed the placental barrier and was metabolized in hepatocytes. However, in one of cases the patient's father also carried the deletion 2q37.3, but had no liver disease. Therefore, the deletion 2q37.3 may be considered 
Table. Candidate genes associated with BA according to GWAS

\begin{tabular}{|c|c|c|c|c|}
\hline Locus & Ethnic group & Variant & Candidate gene & GWAS \\
\hline $2 \mathrm{q} 37.3$ & Caucasian & Heterozygous deletion & GPC1/AGXT & $23 / 24$ \\
\hline $14 \mathrm{q} 21.3$ & Caucasian & Non-coding SNP & ARF6 & 25 \\
\hline $10 \mathrm{q} 24.2$ & Han Chinese & Non-coding SNP & ADD3/XPNPEP1 & $26 / 27 / 28$ \\
\hline $2 \mathrm{p} .16 .1$ & Caucasian & Non-coding SNP & EFEMP1 & 29 \\
\hline
\end{tabular}

Note: SNP — single nucleotide polymorphism.

a factor contributing to susceptibility to BA, possibly due to biotransformation of xenobiotics.

In the other study the same researchers increased the sample size to 61 patients with BA vs. 5,088 healthy controls [24]. Deletions 2q37.3 of various lengths were identified in six patients $(9.84 \%)$ and four healthy individuals $(0.08 \%)$. However the region of interest contained the deletion of one GPC1 gene copy. The gene encodes glypican ivolved in regulation of Hedgehog signaling and inflammation. Knockdown of gpc1in zebrafish (Danio rerio) overactivated the Hedgehog signaling resulting in the developmental biliary defects, smaller gallbladder and poor bile excretion. In the specimens obtained from patients, reduced GPC1 staining was observed on the apical surface of cholangiocytes. The authors concluded that gene GPC1 appeared to be a BA susceptibility gene.

The case-control study performed by Chinese researchers revealed a possible association with reduced BA risk in 50\% of patients with the following GPC1 haplotypes: $C_{\text {rs2292832 }}$ $C_{\text {rs3828336 }} \& T_{\text {rs } 3828336}$ or $T_{\text {rs } 2292832}-T_{\text {rs } 3828336}$ [30].

\section{Genes $A D D 3$ and XPNPEP1}

During the very first GWAS carried out in Chinese population the 500,000 single-nucleotide polymorphisms (SNP) were genotyped in 200 patients with BA and 481 healthy controls [26]. The strongest overall association was found for rs17095355 located on 10q24.2 between genes XPNPEP1 (X-prolyl aminopeptidase) and ADD3 (adducin 3). However, the authors failed to determine how the intergenic variant could affect the susceptibility to BA, but suggested that regulation of neighboring genes was involved.

ADD3 encodes adducin 3 , the protein belonging to a family of membrane skeletal proteins involved in the spectrin-actin network assembly in erythrocytes, and at sites of cell-cell contact in epithelial tissues, including organs of the gastrointestinal tract, liver and biliary tract [31, 32]. The highest, compared to adults, expression of $A D D 3$ is observed in fetal hepatocytes and cells of biliary ducts [32]. The contraction of intrahepatic bile canaliculi facilitating the bile drainage is controlled by the actin-myosin interaction. It is important to note that during the experiment with medications the impaired interaction resulted in severe cholestasis [33]. Increased accumulation of actin and myosin around bile canaliculi was observed in patients with BA who did not exhibit bile flow after surgery [34]. Moreover, the $\alpha$-smooth-muscle actin expression intensity correlated with the degree of fibrosis in patients with BA [35].

XPNPEP1 is expressed in the biliary epithelial cells [36], it encodes the soluble X-prolyl aminopeptidase or the soluble aminopeptidase P (APP1). The APP1 enzyme contributes to degradation of bradykinin (BK) and substance $P$ (SP) [37]. Bradykinin is involved in vasodilation and vascular permeability, the expression of bradykinin is regulated directly by the nuclear bile acid receptor, farnesoid $X$ receptor ( $F X R)$, which plays a part in regulation of bile acid synthesis and secretion, and is involved in inflammation [38-39]. The inflammatory mediator $\mathrm{SP}$ is also involved in regulation of bile secretion, hepatobiliary transport and innervation of the liver. The role of hepatobiliary transporters (particularly the FXR) was studied in murine models [40].

This study attracted attention to locus 10q24.2. Several studies of the locus were carried out in different populations [41-46]. It's worth mentioning that the significant association between the described polymorphism rs17095355 and BA was also revealed in Thai population [42].

However, the study of the North American patients' cohort revealed no association to $\mathrm{r}$ 17095355, but revealed the association of BA and the other SNP (rs7099604), located in intron 1 of the $A D D 3$ gene [41]. The quantitative PCR detected significant differences in the expression of $A D D 3$, not XPNPEP1, in liver tissue between diseased and healthy individuals, but there were no differences in the $A D D 3$ nucleotide sequence between the groups. Therefore, the diseased individuals may have alterations in the non-coding regulatory DNA regions or epigenetic modifications.

In 2020, the association of three SNPs in ADD3 (rs17095355, rs10509906 and rs2501577) and two SNPs in GPC1 (rs6750380 and rs6707262) with BA in the group of Chinese patients ( $n=340$ ) was validated [59].

The first model of BA using the induced pluripotent stem cells (iPSCs) was developed in 2019 [60]. The iPSCs obtained from the BA patients' blood differentiated in vitro into pathological cholangiocytes with signs of fibrosis. The researchers integrated the BA-associated SNP in GPC1 and ADD3 in healthy iPSCs using the CRISPR/Cas9 system and induced the biliary differentiation. These cells reproduced the pathological development of cholangiocytes as BA-specific iPSCs. The iPSC-based models of BA hold great promise for further study of the BA pathogenesis.

\section{Gene ARF6}

The BA-associated SNPs rs3126184 and rs10140366 in ARF (ADP-ribosylation factor) located in $14 \mathrm{q} 21.3$ were identified in 2015 [25]. The minor alleles of these polymorphisms were associated with reduced expression of ARF6.

Genes ARF6, GPC1 and ADD3 have similar functions in the formation and development of the biliary tract. GPC1 and ARF6 are involved in FGF (fibroblast growth factor) and EGF (epidermal growth factor) signaling playing an important role in organogenesis. Along with ADD3, ARF6 regulates the actin cytoskeleton remodeling, affects the cellular motility and intercellular junctions. ARF6 is activated by binding to the EGF receptor (EGFR) with its activator GEP100, which in turn sequentially triggers other reactions. The further activation of EGFR-GEP100-ARF6 results in activation of MAPK/ERKCREB signaling cascade, which ultimately affects normal cell development and proliferation [49-52].

Currently, there is no single point of view whether changes in the intrahepatic bile ducts are secondary or independently formed. Thus, four infants diagnosed with BA during their first days of life underwent a number of biopsies, which revealed the paucity of intrahepatic bile ducts with no signs of fibrosis 
and cirrhosis always found during Kasai portoenterostomy or liver transplantation [53]. As early as in 1974 Landing proposed that the entire biliary tree was involved in obstructive cholangiopathies: the involvement of intra- and extrahepatic bile ducts hinged of the duration and type of noci-influence [54].

The arf6 knockdown in zebrafish (Danio rerio) larvae resulted in reduced liver size, lower number of biliary epithelial cells, poor bile excretion and impaired development of extraand intrahepatic bile ducts. Similar effects were observed upon injection of EGFR inhibitor. The authors note that the EGFRArf6 signaling pathway may contribute to the intrahepatic bile ducts morphogenesis [25].

Thus, in two of 29 biopsy specimens taken from patients with BA the weak ARF6 immunostaining was detected, as well as the reduced number of intrahepatic bile ducts with signs of fibrosis. Based on these data the authors suggested that the ARF6 expression downregulation facilitated the defective formation of both extra- and intrahepatic biliary network [25].

\section{Gene EFEMP1}

The new susceptibility locus for BA in 2p.16.1 was revealed both in infants with isolated form of BA and with BA combined with other abnormalities [55]. The three BA-associated SNPs, rs10865291, rs6761893 and rs727878B, were detected within intron 5 of EFEMP1 gene of the described locus. More EFEMP1 transcripts in the liver tissue (mainly in cholangiocytes and portal fibroblasts) were observed in patients with either BA or other cholestatic diseases compared to control group.

EFEMP1 gene encodes fibulin-3 involved in the extracellular matrix remodeling, tissue regeneration and organogenesis [56, 57]. Furthermore, EFEMP1 is an activator of the Notch signaling in vitro, although is less efficient than JAG1 [58]. It is known that fibulins interact closely with laminins and other extracellular proteins. Considering the close contact and proximity of the developing bile ducts with the portal mesenchymal tissue extracellular matrix, we can assume that the EFEMP1 protein is involved in the biliary tract development.

However, the study of Chinese patients with BA performed in 2020 revealed no associations to genes EFEMP1 and ARF6 [59].

\section{Genes STIP1 and REV1}

In 2020, the trio analysis of exomes in 30 families with BA in children revealed 66 de novo variants in 66 genes including potentially deleterious variants in STIP1 and REV1 [61]. The proteins encoded by these genes interact with the heat-shock protein HSP90 and are involved in stress-responses. The other group of researchers introduced mutations to genes stip 1 and rev1 of zebrafish (Danio rerio) using the CRISPR/Cas9 system and exposed the fish to biliatresone: in contrast to wild-type fish, the mutant fish were sensitive to low doses of biliatresone [62]. The in vitro knockdown of these genes in cholangiocytes and exposure to biliatresone disrupted the cytoskeleton. These results support the hypothesis of the environmental contribution to BA in people with genetic susceptibility.

\section{Genes of cholangiocyte cilia}

The trio-WES of 89 families with BA in children was carried out in 2020 [63]. The researchers detected rare deleterious de novo variants in ciliary genes of $31.5 \%$ patients and identified three candidate genes: KIF3B, PCNT and TTC17. The patients carrying mutations in these genes had low levels of KIF3B and TTC17 proteins in liver tissue. The knockout of kif3b, pcnt and ttc17 using the CRISPR/Cas9 system resulted in impaired bile outflow in zebrafish (Danio rerio) larvae. The researchers suggest that the defective cilia may cause hyperactivation of Hedgehog signaling. Abnormal cholangiocytes may also be damaged by bile, which facilitates $\mathrm{Hh}$ signaling and leads to inflammation and fibrosis.

\section{Genetic factors contributing to the outcome of BA}

Specific genetic characteristic of the patient may significantly affect the disease severity. Despite the BA phenotypic heterogeneity, there are relatively few studies of genetic factors contributing to the surgical treatment (Kasai portoenterostomy) outcome. According to some authors, such genes as A1AT, JAG1 and CFTR may contribute to surgical outcome [64-68].

The $\alpha 1$ antitrypsin deficiency is a monogenic autosomal recessive disorder (A1AT ZZ genotype) leading to liver disease in children. It has been shown that pathological alleles like Z, S, etc. (heterozygous) are more common in children with chronic liver disease $(n=241)$, including those with BA $(n=67)$, than in general population [69]. The BA children with such genotypes had lower age of liver transplant compared to BA children with normal MM genotype.

The WES analysis of DNA extracted from liver biopsies of 20 patients with BA obtained during portoenterostomy was carried out in Thailand [70]. After surgery, only seven patients showed signs of jaundice clearance, three patients improved partially, and in 10 patients, surgery had no effect. The 13 rare variants in nine genes responsible for known diseases, including cholestatic disorders, were identified in BA patients (no clinical manifestations of these disorders were observed): JAG1 (Alagille syndrome, AGS); MYO5B (congenital microvillus atrophy progressive familial intrahepatic cholestasis type 6); ABCB11 (familial intrahepatic cholestasis type 2); ABCC2 (Dubin-Johnson syndrome); ERCC4 (Fanconi anemia); KCNH1 (Zimmermann-Laband syndrome); MLL2 (Kabuki syndrome); RFX6 (Mitchell-Riley syndrome) and UG1A1 (Crigler-Najjar syndrome type I). The authors suggest that BA and other liver diseases may have shared etiopathogenesis. Such associations are responsible for disease severity and poor prognosis in BA patients with native liver.

The missense JAG1 mutations were identified in nine of 102 BA patients with no typical Alagille syndrome phenotype [71]. According to the authors, children with such variants had worse prognosis and portoenterostomy outcome. However, recent studies have shown that Alagille syndrome (AGS) may mimic BA: five children carrying the pathogenic variant in JAG1 diagnosed with BA in early infancy have developed the typical for AGS clinical signs by 3 years, of age [72].

\section{Contribution of hepatocellular transporters and nuclear bile acid receptors to portoenterostomy outcome}

Over the past decade the large amount of data was obtained describing the liver regeneration due to regulation of hepatocellular transporters (BSEP, MDR1, MDR3, OSTb) and nuclear bile acid receptors (FXR, PXR, CAR) activity in the context of cholestasis [73-75].

Liver adapts well to bile acids accumulation. It has been found that in healthy children the genetic deficiency of these receptors is of no clinical significance due to mechanisms of compensation. However, in patients with cholestatic disorders, including BA, the described alterations may become additional factors affecting the pathologic process. In case of hepatocellular transporters normal functioning 
hepatocytes are protected from the toxic effect of bile acids due to their elimination by the BSEP transporter, and the biliary epithelium is protected due to major transporters FIC1 and MDR3 [76].

Based on these data, the studies has been carried out aimed at assessment of hepatic nuclear factors and hepatocellular transporters expression levels as predictors of KPE outcome in children with BA.

It was found that the expression of PXR and/or CAR receptor genes in the liver tissue of patients with poor KPE outcomes was significantly lower compared to patients with favourable outcomes. Five of six patients with low expression of both genes required liver transplant before one year of age (7-11 months) [75]. It had been previously shown that in Pxr knockout rats the liver damage caused by bile acids accumulation was significantly higher compared to healthy animals $[77,78]$. It is believed that low levels of CAR and PXR may be associated both with genetic factors and inflammation. It has been determined that these nuclear bile acid receptors mediate the bile acid homeostasis by binding bile acids, are transported to nucleus and downregulate genes encoding the enzymes involved in the bile acids synthesis and reabsorption. At the same time they upregulate genes encoding transporters BSEP, MRP4 and OST $\alpha$-OST $\beta$ responsible for export of bile acids from hepatocytes [79-90].

WES analysis was carried out aimed at searching for genetic variants more common in BA patients who required the liver transplant at early age due to no KPE effect than in children with native liver [91]. Among 98 children who required the liver transplant at early age the nonsynonimous variant p.A934T in ABCB4 was more common compared to a group of children ( $n=97$ ) who survived portoenterostomy with their native liver. Downregulation of $A B C B 4$ encoding MDR3 leads to the decrease in biliary phospholipids level, thus leading to bile acids damaging cholangiocytes.

The whole transcriptome mRNA sequencing of 29 liver samples obtained from patients with BA and differential expression analysis carried out in 2020 [92] identified the potential determinants of the KPE outcome: matrix metalloproteinase 7 (MMP7) and phosphoenolpyruvate carboxykinase (PCK1). MMP7 enzyme is involved in extracellular matrix remodeling in liver fibrosis; PCK1 is involved in gluconeogenesis, and its role in BA remains unclear. MMP7 expression was significantly elevated in patients who failed to clear jaundice after KPE as well as in patients with end stage liver disease. In contrast, PCK1 level was upregulated in patients who had successful $\mathrm{KPE}$, while there was a significant downregulation in patients who failed KPE.

\section{References}

1. Davenport M, et al. Biliary atresia in England and Wales: results of centralization and new benchmark. Journal of Pediatric Surgery. 2011; 46 (9): 1689-94.

2. Tiao MM, et al. Epidemiological features of biliary atresia in Taiwan, a national study 1996-2003. Journal of gastroenterology and hepatology. 2008; 23 (1): 62-66.

3. Volynec GV, i dr. Differencial'naja diagnostika vrozhdennyh holestaticheskih boleznej u detej. Jeksperimental'naja klinicheskaja gastrojenterologija. 2017; 8 (144): 67-74. Russian.

4. Filippova EA, i dr. Jehograficheskie izmenenija organov brjushnoj polosti u detej s biliarnoj atreziej i sindromom Alazhilja $v$ techenie pervyh 3 mesjacev zhizni. Pediatrija. Prilozhenie k zhurnalu Consilium Medicum. 2017; 4, 93. Russian.
Thus, the expression patterns of various genes in liver tissue and bile ducts may be used as biomarkers for prediction of KPE outcome allowing the healthcare specialists to develop new BA treatment strategies.

\section{Epigenetic factors}

The BA pathogenesis may be based on epigenetic modifications (for example, DNA methylation, histone modifications, expression of non-coding RNA. etc.). DNA methylation was significantly reduced in bile duct cells from BA patients compared to patients with other cholestatic disorders [93]. That could lead to IFN $\gamma$-sugnaling activation and inflammation. Various epigenetic modifications were identified in peripheral blood leukocytes (for example, CD4 ${ }^{+} \mathrm{T}$, Treg) of a number of BA patients [94-97].

It has been shown that hypomethylated PDGFA gene (platelet derived growth factor subunit $A$ ) is upregulated in the affected liver biopsy specimens possibly contributing to the BA pathogenesis [98]. The PDGF family proteins induce proliferative and fibrotic disorders in many organs. Thus, the variant rs9690350 $(\mathrm{G}>\mathrm{C})$ in PDGFA was associated with increased risk of BA in 506 BA patients when compared to 1473 healthy individuals [99].

The expression level of some miRNAs in the liver of BA patients was different compared to a group of healthy individuals. For example, mir-29b and mir-142-5p were overexpressed in the liver, despite the fact they targeted genes encoding key enzymes DNMT1 and DNMT3 involved in DNA methylation [100]. The other miRNA, mir-145-5p, targeted ADD3 gene, it was downregulated in liver tissue of some BA patients [101].

\section{CONCLUSION}

Despite years of study the etiology of BA remains poorly understood. Genetic research revealed no specific alterations. The disorder appears to have multifactorial etiology, which includes genetic alterations (inherited or somatic mutations), and epigenetic modifications due to genetic alterations or environmental factors (toxins, viruses).

The BA surgical correction (Kasai portoenterostomy) proposed as early as in 1955 makes it possible to preserve the liver function and to postpone transplantation. The factors affecting the surgical intervention effect and overall survival in patients with native liver remain understudied. Specific genetic characteristic of the patient as well as expression patterns of various genes in liver tissue and bile ducts are considered as prognostic biomarkers. However, further research is required.
5. Razumovskij AYu, Degtjareva AV, Kulikova NV, Rachkov VE, Ratnikov S A, Filippova EA, i dr. Otdalennye rezul'taty lechenija detej s biliarnoj atreziej. Rossijskij vestnik perinatologii i pediatrii. 2019; 64 (1): 46-55. Russian.

6. Kozlov YuA, i dr. Sovremennyj vzgljad na proishozhdenie biliarnoj atrezii. Annaly hirurgii. 2017; 22 (2): 73-80. Russian.

7. Ortiz-Perez A, et al. Innate Immunity and Pathogenesis of Biliary Atresia. Frontiers in Immunology. 2020; 11: 329.

8. Lampela $\mathrm{H}$, et al. Native liver histology after successful portoenterostomy in biliary atresia. Journal of clinical gastroenterology. 2014; 48 (8): 721-8.

9. Soufi N, Bazerbachi F, Deneau M. Post-transplant disease recurrence in pediatric PSC. Current gastroenterology reports. 
2018; 20 (9): 44.

10. Vij M, Rela M. Biliary atresia: pathology, etiology and pathogenesis. Future Science OA. 2020; 00: FSO466. https://www.futurescience.com/doi/full/10.2144/fsoa-2019-0153

11. Averbukh LD, Wu GY. Evidence for viral induction of biliary atresia: a review. Journal of Clinical and Translational Hepatology. 2018; 6 (49): 410.

12. Rauschenfels $\mathrm{S}$, et al. Incidence of hepatotropic viruses in biliary atresia. European journal of pediatrics. 2009; 168 (4): 469-76.

13. Zani A, et al. Cytomegalovirus-associated biliary atresia: an aetiological and prognostic subgroup. Journal of pediatric surgery. 2015; 50 (910): 1739-45.

14. Sergi CM. Genetics of biliary atresia: a work in progress for a disease with an unavoidable sequela into liver cirrhosis following failure of hepatic portoenterostomy. Liver Cirrhosis-Debates and Current Challenges. IntechOpen, 2019. Dostupno po ssylke: https://www.intechopen.com/books/liver-cirrhosis-debatesand-current-challenges/genetics-of-biliary-atresia-a-work-inprogress-for-a-disease-with-an-unavoidable-sequela-into-liver- .

15. Lakshminarayanan B, Davenport M. Biliary atresia: a comprehensive review. Journal of autoimmunity. 2016; 73: 1-9.

16. Lorent $\mathrm{K}$, et al. Identification of a plant isoflavonoid that causes biliary atresia. Science translational medicine. 2015; 7 (286): 286ra67-286ra67.

17. Zhao X, et al. Glutathione antioxidant pathway activity and reserve determine toxicity and specificity of the biliary toxin biliatresone in zebrafish. Hepatology. 2016; 64 (3): 894-907.

18. Kobayashi $\mathrm{K}$, et al. Mother-to-daughter occurrence of biliary atresia: a case report. Journal of pediatric surgery. 2008; 43 (8): 1566-8.

19. Girard M, Panasyuk G. Genetics in biliary atresia. Current opinion in gastroenterology. 2019; 35 (2): 73-81.

20. Xu X, Zhan J. Biliary atresia in twins: a systematic review and meta-analysis. Pediatric Surgery International, 2020. Available from: https://link.springer.com/article/10.1007/s00383-02004690-4.

21. Gou Q, et al. Biliary atresia in twins' population: a retrospective multicenter study in mainland China. Pediatric Surgery International. 2020; p. 1-8.

22. Fabre A, Roman C, Roquelaure B. Somatic mutation, a cause of biliary atresia: A hypothesis. Medical Hypotheses. 2017; 102: 91-93.

23. Leyva-Vega M, et al. Genomic alterations in biliary atresia suggest region of potential disease susceptibility in $2 q 37$. 3. American journal of medical genetics Part A. 2010; 152 (4): 886-95.

24. Cui $\mathrm{S}$, et al. Evidence from human and zebrafish that GPC1 is a biliary atresia susceptibility gene. Gastroenterology. 2013; 144 (5): 1107-15

25. Ningappa $M$, et al. The role of ARF6 in biliary atresia. PloS one. 2015; 10 (9): e0138381.

26. Garcia-Barceló MM, et al. Genome-wide association study identifies a susceptibility locus for biliary atresia on 10q24. 2 . Human molecular genetics. 2010; 19 (14): 2917-25.

27. Tsai EA, et al. Replication of a GWAS signal in a Caucasian population implicates ADD3 in susceptibility to biliary atresia. Human genetics. 2014; 133 (2): 235-43.

28. Kaewkiattiyot $\mathrm{S}$, et al. Association of $\mathrm{X}$-prolyl aminopeptidase 1 rs17095355 polymorphism with biliary atresia in Thai children. Hepatology Research. 2011; 41 (12): 1249-52.

29. Chen $Y$, et al. A genome-wide association study identifies a susceptibility locus for biliary atresia on $2 p 16.1$ within the gene EFEMP1. PLoS genetics. 2018; 14 (8): e1007532.

30. Ke J, et al. Common genetic variants of GPC1 gene reduce risk of biliary atresia in a Chinese population. Journal of pediatric surgery. 2016; 51 (10): 1661-4.

31. Citterio $L$, et al. Expression analysis of the human adducin gene family and evidence of ADD2 $\beta 4$ multiple splicing variants. Biochemical and biophysical research communications. 2003; 309 (2): 359-67.

32. Ku NO, et al. The cytoskeleton of digestive epithelia in health and disease. American Journal of Physiology-Gastrointestinal and Liver Physiology. 1999; 277 (6): G1108-G1137.

33. Oshio C, Phillips MJ. Contractility of bile canaliculi: implications for liver function. Science. 1981; 212 (4498): 1041-2.

34. Segawa $\mathrm{O}$, et al. Actin and myosin deposition around bile canaliculi: a predictor of clinical outcome in biliary atresia. Journal of pediatric surgery. 1993; 28 (6): 851-6.

35. Shteyer $\mathrm{E}$, et al. Outcome after portoenterostomy in biliary atresia: pivotal role of degree of liver fibrosis and intensity of stellate cell activation. Journal of pediatric gastroenterology and nutrition. 2006; 42 (1): 93-99.

36. Nagasaka T, et al. Immunohistochemical localization of placental leucine aminopeptidase/oxytocinase in normal human placental, fetal and adult tissues. Reproduction, fertility and development. 1997; 9 (8): 747-54.

37. Hooper NM, et al. Protease-activated receptors: the role of cellsurface proteolysis in signalling. Essays in Biochemistry. 2002; 38: $169-83$.

38. Sharma JN. Hypertension and the bradykinin system. Current hypertension reports. 2009; 11 (3): 178-81.

39. Zhao A, et al. Human kininogen gene is transactivated by the farnesoid X receptor. Journal of Biological Chemistry. 2003; 278 (31): 28765-70.

40. Yang $\mathrm{H}$, et al. Inflammation mediated down-regulation of hepatobiliary transporters contributes to intrahepatic cholestasis and liver damage in murine biliary atresia. Pediatric research. 2009; 66 (4): 380-5.

41. Tsai EA, et al. Replication of a GWAS signal in a Caucasian population implicates ADD3 in susceptibility to biliary atresia. Human genetics. 2014; 133 (2): 235-43.

42. Kaewkiattiyot $\mathrm{S}$, et al. Association of X-prolyl aminopeptidase 1 rs17095355 polymorphism with biliary atresia in Thai children. Hepatology Research. 2011; 41 (12): 1249-52.

43. Cheng $\mathrm{G}$, et al. Common genetic variants regulating ADD3 gene expression alter biliary atresia risk. Journal of hepatology. 2013; 59 (6): 1285-91.

44. Zeng $\mathrm{S}$, et al. Association between single nucleotide polymorphisms in the ADD3 gene and susceptibility to biliary atresia. PloS one. 2014; 9 (10): e107977.

45. Wang Z, et al. The intragenic epistatic association of ADD3 with biliary atresia in Southern Han Chinese population. Bioscience reports. 2018; 38 (3). Dostupno po ssylke: https://portlandpress. com/bioscirep/article/38/3/BSR20171688/57837/Theintragenic-epistatic-association-of-ADD3-with.

46. Laochareonsuk W, Chiengkriwate $\mathrm{P}$, Sangkhathat S. Single nucleotide polymorphisms within Adducin 3 and Adducin 3 antisense RNA1 genes are associated with biliary atresia in Thai infants. Pediatric surgery international. 2018; 34 (5): 515-20.

47. Jing Li, et al. Association between rs17095355 polymorphism on 10 q24 and susceptibility to biliary atresia: a meta-analysis. The Journal of Maternal-Fetal \& Neonatal Medicine. 2017; 30 (15): 1882-6.

48. Tang, Vivian, et al. Loss of a candidate biliary atresia susceptibility gene, add3a, causes biliary developmental defects in zebrafish. Journal of pediatric gastroenterology and nutrition. 2016; 63 (5): 524.

49. Iguchi $\mathrm{H}$, et al. cAMP response element-binding protein (CREB) is required for epidermal growth factor (EGF)-induced cell proliferation and serum response element activation in neural stem cells isolated from the forebrain subventricular zone of adult mice. Endocrine journal. 2011: 1106100583-1106100583.

50. Sarró E, et al. Phosphoinositide 3-kinase inhibitors protect mouse kidney cells from cyclosporine-induced cell death. Kidney international. 2008; 73 (1): 77-85.

51. Hu ZZ, et al. GEP100/Arf6 is required for epidermal growth factor-induced ERK/Rac1 signaling and cell migration in human hepatoma HepG2 cells. PloS one. 2012; 7 (6): e38777.

52. Sabe H, et al. The EGFR-GEP100-Arf6-AMAP1 signaling pathway specific to breast cancer invasion and metastasis. Traffic. 2009; 10 (8): 982-93.

53. Azar G, et al. Atypical morphologic presentation of biliary atresia and value of serial liver biopsies. Journal of pediatric gastroenterology and nutrition. 2002; 34 (2): 212-5.

54. Landing $\mathrm{BH}$, Wells TR, Ramicone E. Time course of the intrahepatic lesion of extrahepatic biliary atresia: a morphometric study. Pediatric pathology. 1985; 4 (3-4): 309-19. 
55. Chen $Y$, et al. A genome-wide association study identifies a susceptibility locus for biliary atresia on 2p16. 1 within the gene EFEMP1. PLoS genetics. 2018; 14 (8): e1007532.

56. De Vega S, Iwamoto T, Yamada Y. Fibulins: multiple roles in matrix structures and tissue functions. Cellular and molecular life sciences. 2009; 66 (11-12): 1890-902.

57. Timpl R, et al. Fibulins: a versatile family of extracellular matrix proteins. Nature reviews Molecular cell biology. 2003; 4 (6): 479-89.

58. Hu B, et al. Fibulin-3 promotes glioma growth and resistance through a novel paracrine regulation of Notch signaling. Cancer research. 2012; 72 (15): 3873-85.

59. Bai MR, et al. Association of common variation in ADD3 and GPC1 with biliary atresia susceptibility. Aging (Albany NY). 2020; 12 (8): 7163

60. Tian L, et al. Biliary atresia relevant human induced pluripotent stem cells recapitulate key disease features in a dish. Journal of pediatric gastroenterology and nutrition. 2019; 68 (1): 56.

61. Rajagopalan $R$, et al. exome Sequencing in individuals with isolated Biliary Atresia. Scientific reports. 2020; 10 (1): 1-8.

62. Zhao $X$, et al. Impaired redox and protein homeostasis as risk factors and therapeutic targets in toxin-induced biliary atresia. Gastroenterology. 2020. Available from: https://www. sciencedirect.com/science/article/pii/S0016508520347545.

63. Lam WY, et al. Whole exome sequencing reveals a wide spectrum of ciliary gene mutations in nonsyndromic biliary atresia. medRxiv. 2020. Dostupno po ssylke: https://www.medrxiv.org/content/10 .1101/2020.05.05.20091504v1.full.pdf.

64. Petersen C, Davenport M. Aetiology of biliary atresia: what is actually known? Orphanet journal of rare diseases. 2013; 8 (1): 128.

65. Cui S, et al. Evidence from human and zebrafish that GPC1 is a biliary atresia susceptibility gene. Gastroenterology. 2013; 144 (5): 1107-15.

66. Rock N, McLin V. Liver involvement in children with ciliopathies. Clinics and research in hepatology and gastroenterology. 2014; 38 (4): 407-14.

67. Miethke AG, Huppert SS. Fishing for biliary atresia susceptibility genes. Gastroenterology. 2013; 144 (5): 878.

68. Zhao D, Long XD, Xia Q. Recent advances in etiology of biliary atresia. Clinical pediatrics. 2015; 54 (8): 723-31.

69. Campbell KM, et al. High prevalence of $\alpha$-1-antitrypsin heterozygosity in children with chronic liver disease. Journal o pediatric gastroenterology and nutrition. 2007; 44 (1): 99-103.

70. Sangkhathat $S$, et al. Variants associated with infantile cholestatic syndromes detected in extrahepatic biliary atresia by whole exome studies: a 20-case series from Thailand. Journal of pediatric genetics. 2018; 7 (2): 67

71. Kohsaka T, et al. The significance of human jagged 1 mutations detected in severe cases of extrahepatic biliary atresia. Hepatology. 2002; 36 (4): 904-12

72. Dědič $\mathrm{T}$, et al. Alagille syndrome mimicking biliary atresia in early infancy. PLoS One. 2015; 10 (11): e0143939.

73. Linton KJ. Lipid flopping in the liver. Biochemical Society Transactions. 2015; 43 (5): 1003-10.

74. Groen A, et al. Complementary functions of the flippase ATP8B1 and the floppase ABCB4 in maintaining canalicular membrane integrity. Gastroenterology. 2011; 141 (5): 1927-37.

75. Chen HL, et al. Expression of hepatocyte transporters and nuclear receptors in children with early and late-stage biliary atresia. Pediatric research. 2008; 63 (6): 667-3.

76. Chen HL, et al. Jaundice revisited: recent advances in the diagnosis and treatment of inherited cholestatic liver diseases. Journal of biomedical science. 2018; 25 (1): 75

77. Wagner $\mathrm{M}$, et al. Role of farnesoid $\mathrm{X}$ receptor in determining hepatic ABC transporter expression and liver injury in bile ductligated mice. Gastroenterology. 2003; 125 (3): 825-38.

78. Stedman CAM, et al. Nuclear receptors constitutive androstane receptor and pregnane $X$ receptor ameliorate cholestatic liver injury. Proceedings of the National Academy of Sciences. 2005; 102 (6): 2063-8.

79. Wagner $\mathrm{M}$, et al. CAR and PXR agonists stimulate hepatic bile acid and bilirubin detoxification and elimination pathways in mice.
Hepatology. 2005; 42 (2): 420-30.

80. Makishima M. Nuclear receptors as targets for drug development: regulation of cholesterol and bile acid metabolism by nuclear receptors. Journal of pharmacological sciences. 2005; 97 (2): 177-83

81. Boyer JL. Nuclear receptor ligands: rational and effective therapy for chronic cholestatic liver disease? Gastroenterology. 2005; 129 (2): $735-40$

82. Keppler D. The roles of MRP2, MRP3, OATP1B1, and OATP1B3 in conjugated hyperbilirubinemia. Drug Metabolism and Disposition. 2014; 42 (4): 561-5.

83. Schroeder RJ, et al. Cholesterol and sphingolipid enhance the Triton X-100 insolubility of glycosylphosphatidylinositol-anchored proteins by promoting the formation of detergent-insoluble ordered membrane domains. Journal of Biological Chemistry. 1998; 273 (2): 1150-7.

84. Guyot C, Stieger B. Interaction of bile salts with rat canalicular membrane vesicles: evidence for bile salt resistant microdomains. Journal of hepatology. 2011; 55 (6): 1368-76.

85. Linton KJ. Lipid flopping in the liver. Biochemical Society Transactions. 2015; 43 (5): 1003-10.

86. Groen A, et al. Complementary functions of the flippase ATP8B1 and the floppase ABCB4 in maintaining canalicular membrane integrity. Gastroenterology. 2011; 141 (5): 1927-37.

87. Wang $\mathrm{H}$, et al. Endogenous bile acids are ligands for the nuclear receptor FXR/BAR. Molecular cell. 1999; 3 (5): 543-53.

88. Parks DJ, et al. Bile acids: natural ligands for an orphan nuclear receptor. Science. 1999; 284 (5418): 1365-8.

89. Makishima $\mathrm{M}$, et al. Identification of a nuclear receptor for bile acids. Science. 1999; 284 (5418): 1362-5.

90. Modica S, Gadaleta RM, Moschetta A. Deciphering the nuclear bile acid receptor FXR paradigm. Nuclear receptor signaling. 2010; 8 (1): nrs. 08005. Available from: https://journals.sagepub. com/doi/pdf/10.1621/nrs.08005.

91. Mezina A, et al. 845 Whole Exome Sequencing Identifies ABCB4 Gene Variants As Modifiers of Biliary Atresia Outcomes. Gastroenterology. 2014; 146 (5): S-928.

92. Ramachandran $P$, et al. RNA-seq reveals outcome-specific gene expression of MMP7 and PCK1 in biliary atresia. Molecular biology reports. 2019; 46 (5): 5123-30

93. Matthews RP, et al. DNA hypomethylation causes bile duct defects in zebrafish and is a distinguishing feature of infantile biliary atresia. Hepatology. 2011; 53 (3): 905-14.

94. Dong R, Zhao R, Zheng S. Changes in epigenetic regulation of CD4+ T Iymphocytesin biliary atresia. Pediatric research. 2011; 70 (6): 555-9.

95. Dong $\mathrm{R}$, et al. Abnormal DNA methylation of ITGAL (CD11a) in $\mathrm{CD}^{+} \mathrm{T}$ cells from infants with biliary atresia. Biochemical and biophysical research communications. 2012; 417 (3): 986-90.

96. Udomsinprasert W, et al. Global methylation, oxidative stress, and relative telomere length in biliary atresia patients. Scientific reports. 2016; 6: 26969.

97. Li K, et al. Foxp3 promoter methylation impairs suppressive function of regulatory $T$ cells in biliary atresia. American Journal of Physiology-Gastrointestinal and Liver Physiology. 2016; 311 (6): G989-G997.

98. Cofer ZC, et al. Methylation microarray studies highlight PDGFA expression as a factor in biliary atresia. PloS one. 2016; 11 (3): e0151521.

99. Liu F, et al. PDGFA gene rs9690350 polymorphism increases biliary atresia risk in Chinese children. Bioscience reports. 202; 40 (7). Available from: https://portlandpress.com/bioscirep/ article/40/7/BSR20200068/225782/PDGFA-gene-rs9690350polymorphism-increases.

100. Yang $Y$, et al. MicroRNA-29b/142-5p contribute to the pathogenesis of biliary atresia by regulating the IFN- $\gamma$ gene. Cell death \& disease. 2018; 9 (5): 1-9.

101. Ye $Y$, et al. Downregulation of microRNA-145 may contribute to liver fibrosis in biliary atresia by targeting ADD3. PloS one. 2017 . 12 (9): e0180896. 


\section{Литература}

1. Davenport M, et al. Biliary atresia in England and Wales: results of centralization and new benchmark. Journal of Pediatric Surgery. 2011; 46 (9): 1689-94.

2. Tiao MM, et al. Epidemiological features of biliary atresia in Taiwan, a national study 1996-2003. Journal of gastroenterology and hepatology. 2008; 23 (1): 62-66.

3. Волынец Г. В. и др. Дифференциальная диагностика врожденных холестатических болезней у детей. Экспериментальная и клиническая гастроэнтерология. 2017; 8 (144): 67-74.

4. Филиппова Е. А. и др. Эхографические изменения органов брюшной полости у детей с билиарной атрезией и синдромом Алажиля в течение первых 3 месяцев жизни. Педиатрия. Приложение к журналу Consilium Medicum. 2017; 4, 93.

5. Разумовский А. Ю., Дегтярева А. В., Куликова Н. В., Рачков В. Е., Ратников С. А., Филиппова Е. А. и др. Отдаленные результаты лечения детей с билиарной атрезией. Российский вестник перинатологии и педиатрии. 2019; 64 (1): 46-55.

6. Козлов Ю. А. и др. Современный взгляд на происхождение билиарной атрезии. Анналы хирургии. 2017; 22 (2): 73-80.

7. Ortiz-Perez A, et al. Innate Immunity and Pathogenesis of Biliary Atresia. Frontiers in Immunology. 2020; 11: 329.

8. Lampela $\mathrm{H}$, et al. Native liver histology after successful portoenterostomy in biliary atresia. Journal of clinical gastroenterology. 2014; 48 (8): 721-8.

9. Soufi N, Bazerbachi F, Deneau M. Post-transplant disease recurrence in pediatric PSC. Current gastroenterology reports. 2018; 20 (9): 44.

10. Vij M, Rela M. Biliary atresia: pathology, etiology and pathogenesis. Future Science OA. 2020; 00: FSO466. https://www.futurescience.com/doi/full/10.2144/fsoa-2019-0153

11. Averbukh LD, Wu GY. Evidence for viral induction of biliary atresia: a review. Journal of Clinical and Translational Hepatology. 2018; 6 (49): 410.

12. Rauschenfels $\mathrm{S}$, et al. Incidence of hepatotropic viruses in biliary atresia. European journal of pediatrics. 2009; 168 (4): 469-76.

13. Zani A, et al. Cytomegalovirus-associated biliary atresia: an aetiological and prognostic subgroup. Journal of pediatric surgery. 2015; 50 (910): 1739-45.

14. Sergi CM. Genetics of biliary atresia: a work in progress for a disease with an unavoidable sequela into liver cirrhosis following failure of hepatic portoenterostomy. Liver Cirrhosis-Debates and Current Challenges. IntechOpen, 2019. Доступно по ссылке: https://www.intechopen.com/books/liver-cirrhosis-debatesand-current-challenges/genetics-of-biliary-atresia-a-work-inprogress-for-a-disease-with-an-unavoidable-sequela-into-liver-.

15. Lakshminarayanan B, Davenport M. Biliary atresia: a comprehensive review. Journal of autoimmunity. 2016; 73: 1-9.

16. Lorent $\mathrm{K}$, et al. Identification of a plant isoflavonoid that causes biliary atresia. Science translational medicine. 2015; 7 (286): 286ra67-286ra67.

17. Zhao X, et al. Glutathione antioxidant pathway activity and reserve determine toxicity and specificity of the biliary toxin biliatresone in zebrafish. Hepatology. 2016; 64 (3): 894-907.

18. Kobayashi K, et al. Mother-to-daughter occurrence of biliary atresia: a case report. Journal of pediatric surgery. 2008; 43 (8): 1566-8.

19. Girard M, Panasyuk G. Genetics in biliary atresia. Current opinion in gastroenterology. 2019; 35 (2): 73-81.

20. Xu X, Zhan J. Biliary atresia in twins: a systematic review and meta-analysis. Pediatric Surgery International, 2020. Доступно по ссылке: https://link.springer.com/article/10.1007/s00383020-04690-4.

21. Gou Q, et al. Biliary atresia in twins' population: a retrospective multicenter study in mainland China. Pediatric Surgery International. 2020; p. 1-8.

22. Fabre A, Roman C, Roquelaure B. Somatic mutation, a cause of biliary atresia: A hypothesis. Medical Hypotheses. 2017; 102 : 91-93.

23. Leyva-Vega $\mathrm{M}$, et al. Genomic alterations in biliary atresia suggest region of potential disease susceptibility in 2 q37. 3. American journal of medical genetics Part A. 2010; 152 (4): 886-95.

24. Cui $\mathrm{S}$, et al. Evidence from human and zebrafish that GPC1 is a biliary atresia susceptibility gene. Gastroenterology. 2013; 144 (5): 1107-15.

25. Ningappa $\mathrm{M}$, et al. The role of ARF6 in biliary atresia. PloS one. 2015; 10 (9): e0138381.

26. Garcia-Barceló MM, et al. Genome-wide association study identifies a susceptibility locus for biliary atresia on 10q24. 2. Human molecular genetics. 2010; 19 (14): 2917-25.

27. Tsai EA, et al. Replication of a GWAS signal in a Caucasian population implicates ADD3 in susceptibility to biliary atresia. Human genetics. 2014; 133 (2): 235-43.

28. Kaewkiattiyot S, et al. Association of X-prolyl aminopeptidase 1 rs17095355 polymorphism with biliary atresia in Thai children. Hepatology Research. 2011; 41 (12): 1249-52.

29. Chen $Y$, et al. A genome-wide association study identifies a susceptibility locus for biliary atresia on 2p16. 1 within the gene EFEMP1. PLoS genetics. 2018; 14 (8): e1007532.

30. Ke J, et al. Common genetic variants of GPC1 gene reduce risk of biliary atresia in a Chinese population. Journal of pediatric surgery. 2016; 51 (10): 1661-4.

31. Citterio $L$, et al. Expression analysis of the human adducin gene family and evidence of ADD2 $\beta 4$ multiple splicing variants. Biochemical and biophysical research communications. 2003; 309 (2): 359-67.

32. Ku NO, et al. The cytoskeleton of digestive epithelia in health and disease. American Journal of Physiology-Gastrointestinal and Liver Physiology. 1999; 277 (6): G1108-G1137.

33. Oshio C, Phillips MJ. Contractility of bile canaliculi: implications for liver function. Science. 1981; 212 (4498): 1041-2.

34. Segawa $\mathrm{O}$, et al. Actin and myosin deposition around bile canaliculi: a predictor of clinical outcome in biliary atresia. Journal of pediatric surgery. 1993; 28 (6): 851-6.

35. Shteyer E, et al. Outcome after portoenterostomy in biliary atresia: pivotal role of degree of liver fibrosis and intensity of stellate cell activation. Journal of pediatric gastroenterology and nutrition. 2006; 42 (1): 93-99.

36. Nagasaka T, et al. Immunohistochemical localization of placental leucine aminopeptidase/oxytocinase in normal human placental, fetal and adult tissues. Reproduction, fertility and development. 1997; 9 (8): 747-54.

37. Hooper NM, et al. Protease-activated receptors: the role of cellsurface proteolysis in signalling. Essays in Biochemistry. 2002; 38: 169-83.

38. Sharma JN. Hypertension and the bradykinin system. Current hypertension reports. 2009; 11 (3): 178-81.

39. Zhao $A$, et al. Human kininogen gene is transactivated by the farnesoid X receptor. Journal of Biological Chemistry. 2003; 278 (31): 28765-70.

40. Yang $\mathrm{H}$, et al. Inflammation mediated down-regulation of hepatobiliary transporters contributes to intrahepatic cholestasis and liver damage in murine biliary atresia. Pediatric research. 2009; 66 (4): 380-5.

41. Tsai EA, et al. Replication of a GWAS signal in a Caucasian population implicates ADD3 in susceptibility to biliary atresia. Human genetics. 2014; 133 (2): 235-43.

42. Kaewkiattiyot $\mathrm{S}$, et al. Association of X-prolyl aminopeptidase 1 rs17095355 polymorphism with biliary atresia in Thai children. Hepatology Research. 2011; 41 (12): 1249-52.

43. Cheng $\mathrm{G}$, et al. Common genetic variants regulating ADD3 gene expression alter biliary atresia risk. Journal of hepatology. 2013; 59 (6): 1285-91.

44. Zeng $\mathrm{S}$, et al. Association between single nucleotide polymorphisms in the ADD3 gene and susceptibility to biliary atresia. PloS one. 2014; 9 (10): e107977.

45. Wang $Z$, et al. The intragenic epistatic association of ADD3 with biliary atresia in Southern Han Chinese population. Bioscience reports. 2018; 38 (3). Доступно по ссылке: https:// portlandpress.com/bioscirep/article/38/3/BSR20171688/57837/ The-intragenic-epistatic-association-of-ADD3-with.

46. Laochareonsuk W, Chiengkriwate P, Sangkhathat S. Single 
nucleotide polymorphisms within Adducin 3 and Adducin 3 antisense RNA1 genes are associated with biliary atresia in Thai infants. Pediatric surgery international. 2018; 34 (5): 515-20.

47. Jing Li, et al. Association between rs17095355 polymorphism on 10q24 and susceptibility to biliary atresia: a meta-analysis. The Journal of Maternal-Fetal \& Neonatal Medicine. 2017; 30 (15) 1882-6.

48. Tang, Vivian, et al. Loss of a candidate biliary atresia susceptibility gene, add3a, causes biliary developmental defects in zebrafish. Journal of pediatric gastroenterology and nutrition. 2016; 63 (5): 524.

49. Iguchi $\mathrm{H}$, et al. cAMP response element-binding protein (CREB) is required for epidermal growth factor (EGF)-induced cell proliferation and serum response element activation in neural stem cells isolated from the forebrain subventricular zone of adult mice. Endocrine journal. 2011: 1106100583-1106100583.

50. Sarró E, et al. Phosphoinositide 3-kinase inhibitors protect mouse kidney cells from cyclosporine-induced cell death. Kidney international. 2008; 73 (1): 77-85

51. Hu ZZ, et al. GEP100/Arf6 is required for epidermal growth factor-induced ERK/Rac1 signaling and cell migration in human hepatoma HepG2 cells. PloS one. 2012; 7 (6): e38777.

52. Sabe H, et al. The EGFR-GEP100-Arf6-AMAP1 signaling pathway specific to breast cancer invasion and metastasis. Traffic. 2009; 10 (8): 982-93.

53. Azar G, et al. Atypical morphologic presentation of biliary atresia and value of serial liver biopsies. Journal of pediatric gastroenterology and nutrition. 2002; 34 (2): 212-5.

54. Landing $\mathrm{BH}$, Wells TR, Ramicone $\mathrm{E}$. Time course of the intrahepatic lesion of extrahepatic biliary atresia: a morphometric study. Pediatric pathology. 1985; 4 (3-4): 309-19.

55. Chen $Y$, et al. A genome-wide association study identifies a susceptibility locus for biliary atresia on 2p16. 1 within the gene EFEMP1. PLoS genetics. 2018; 14 (8): e1007532.

56. De Vega S, Iwamoto T, Yamada Y. Fibulins: multiple roles in matrix structures and tissue functions. Cellular and molecular life sciences. 2009; 66 (11-12): 1890-902.

57. Timpl R, et al. Fibulins: a versatile family of extracellular matrix proteins. Nature reviews Molecular cell biology. 2003; 4 (6): 479-89.

58. Hu B, et al. Fibulin-3 promotes glioma growth and resistance through a novel paracrine regulation of Notch signaling. Cancer research. 2012; 72 (15): 3873-85

59. Bai MR, et al. Association of common variation in ADD3 and GPC1 with biliary atresia susceptibility. Aging (Albany NY). 2020; 12 (8): 7163

60. Tian $L$, et al. Biliary atresia relevant human induced pluripoten stem cells recapitulate key disease features in a dish. Journal of pediatric gastroenterology and nutrition. 2019; 68 (1): 56.

61. Rajagopalan $\mathrm{R}$, et al. exome Sequencing in individuals with isolated Biliary Atresia. Scientific reports. 2020; 10 (1): 1-8.

62. Zhao $X$, et al. Impaired redox and protein homeostasis as risk factors and therapeutic targets in toxin-induced biliary atresia Gastroenterology. 2020. Available from: https://www. sciencedirect.com/science/article/pii/S0016508520347545.

63. Lam WY, et al. Whole exome sequencing reveals a wide spectrum of ciliary gene mutations in nonsyndromic biliary atresia. medRxiv. 2020. Доступно по ссылке: https://www.medrxiv.org/content/1 0.1101/2020.05.05.20091504v1.full.pdf.

64. Petersen C, Davenport M. Aetiology of biliary atresia: what is actually known? Orphanet journal of rare diseases. 2013; 8 (1): 128

65. Cui S, et al. Evidence from human and zebrafish that GPC1 is a biliary atresia susceptibility gene. Gastroenterology. 2013; 144 (5) 1107-15.

66. Rock N, McLin V. Liver involvement in children with ciliopathies Clinics and research in hepatology and gastroenterology. 2014 38 (4): 407-14

67. Miethke AG, Huppert SS. Fishing for biliary atresia susceptibility genes. Gastroenterology. 2013; 144 (5): 878.

68. Zhao D, Long XD, Xia Q. Recent advances in etiology of biliary atresia. Clinical pediatrics. 2015; 54 (8): 723-31.

69. Campbell KM, et al. High prevalence of $\alpha$-1-antitrypsin heterozygosity in children with chronic liver disease. Journal of pediatric gastroenterology and nutrition. 2007; 44 (1): 99-103.
70. Sangkhathat S, et al. Variants associated with infantile cholestatic syndromes detected in extrahepatic biliary atresia by whole exome studies: a 20-case series from Thailand. Journal of pediatric genetics. 2018; 7 (2): 67.

71. Kohsaka T, et al. The significance of human jagged 1 mutations detected in severe cases of extrahepatic biliary atresia. Hepatology. 2002; 36 (4): 904-12.

72. Dědič $\mathrm{T}$, et al. Alagille syndrome mimicking biliary atresia in early infancy. PLoS One. 2015; 10 (11): e0143939.

73. Linton KJ. Lipid flopping in the liver. Biochemical Society Transactions. 2015; 43 (5): 1003-10.

74. Groen A, et al. Complementary functions of the flippase ATP8B1 and the floppase ABCB4 in maintaining canalicular membrane integrity. Gastroenterology. 2011; 141 (5): 1927-37.

75. Chen $\mathrm{HL}$, et al. Expression of hepatocyte transporters and nuclear receptors in children with early and late-stage biliary atresia. Pediatric research. 2008; 63 (6): 667-3.

76. Chen HL, et al. Jaundice revisited: recent advances in the diagnosis and treatment of inherited cholestatic liver diseases. Journal of biomedical science. 2018; 25 (1): 75.

77. Wagner $M$, et al. Role of farnesoid $X$ receptor in determining hepatic ABC transporter expression and liver injury in bile ductligated mice. Gastroenterology. 2003; 125 (3): 825-38.

78. Stedman CAM, et al. Nuclear receptors constitutive androstane receptor and pregnane $X$ receptor ameliorate cholestatic live injury. Proceedings of the National Academy of Sciences. 2005; 102 (6): 2063-8.

79. Wagner $\mathrm{M}$, et al. CAR and PXR agonists stimulate hepatic bile acid and bilirubin detoxification and elimination pathways in mice. Hepatology. 2005; 42 (2): 420-30.

80. Makishima M. Nuclear receptors as targets for drug development: regulation of cholesterol and bile acid metabolism by nuclear receptors. Journal of pharmacological sciences. 2005; 97 (2): 177-83.

81. Boyer JL. Nuclear receptor ligands: rational and effective therapy for chronic cholestatic liver disease? Gastroenterology. 2005; 129 (2): 735-40

82. Keppler D. The roles of MRP2, MRP3, OATP1B1, and OATP1B3 in conjugated hyperbilirubinemia. Drug Metabolism and Disposition. 2014; 42 (4): 561-5.

83. Schroeder RJ, et al. Cholesterol and sphingolipid enhance the Triton X-100 insolubility of glycosylphosphatidylinositol-anchored proteins by promoting the formation of detergent-insoluble ordered membrane domains. Journal of Biological Chemistry. 1998: 273 (2): 1150-7.

84. Guyot C, Stieger B. Interaction of bile salts with rat canalicular membrane vesicles: evidence for bile salt resistant microdomains. Journal of hepatology. 2011; 55 (6): 1368-76.

85. Linton KJ. Lipid flopping in the liver. Biochemical Society Transactions. 2015: 43 (5): 1003-10.

86. Groen A, et al. Complementary functions of the flippase ATP8B1 and the floppase ABCB4 in maintaining canalicular membrane integrity. Gastroenterology. 2011; 141 (5): 1927-37.

87. Wang $\mathrm{H}$, et al. Endogenous bile acids are ligands for the nuclear receptor FXR/BAR. Molecular cell. 1999; 3 (5): 543-53.

88. Parks DJ, et al. Bile acids: natural ligands for an orphan nuclear receptor. Science. 1999; 284 (5418): 1365-8.

89. Makishima $\mathrm{M}$, et al. Identification of a nuclear receptor for bile acids. Science. 1999; 284 (5418): 1362-5.

90. Modica S, Gadaleta RM, Moschetta A. Deciphering the nuclear bile acid receptor FXR paradigm. Nuclear receptor signaling. 2010; 8 (1): nrs. 08005. Available from: https://journals.sagepub. com/doi/pdf/10.1621/nrs.08005

91. Mezina A, et al. 845 Whole Exome Sequencing Identifies ABCB4 Gene Variants As Modifiers of Biliary Atresia Outcomes. Gastroenterology. 2014; 146 (5): S-928.

92. Ramachandran $P$, et al. RNA-seq reveals outcome-specific gene expression of MMP7 and PCK1 in biliary atresia. Molecular biology reports. 2019; 46 (5): 5123-30.

93. Matthews RP, et al. DNA hypomethylation causes bile duct defects in zebrafish and is a distinguishing feature of infantile biliary atresia. Hepatology. 2011; 53 (3): 905-14.

94. Dong $\mathrm{R}$, Zhao $\mathrm{R}$, Zheng $\mathrm{S}$. Changes in epigenetic regulation of 
CD4 ${ }^{+}$T lymphocytesin biliary atresia. Pediatric research. 2011; 70 (6): 555-9.

95. Dong $\mathrm{R}$, et al. Abnormal DNA methylation of ITGAL (CD11a) in $\mathrm{CD} 4^{+} \mathrm{T}$ cells from infants with biliary atresia. Biochemical and biophysical research communications. 2012; 417 (3): 986-90.

96. Udomsinprasert W, et al. Global methylation, oxidative stress, and relative telomere length in biliary atresia patients. Scientific reports. 2016; 6: 26969.

97. Li K, et al. Foxp3 promoter methylation impairs suppressive function of regulatory T cells in biliary atresia. American Journal of Physiology-Gastrointestinal and Liver Physiology. 2016; 311 (6): G989-G997.

98. Cofer ZC, et al. Methylation microarray studies highlight PDGFA expression as a factor in biliary atresia. PloS one. 2016; 11 (3): e0151521.

99. Liu F, et al. PDGFA gene rs9690350 polymorphism increases biliary atresia risk in Chinese children. Bioscience reports. 202; 40 (7). Available from: https://portlandpress.com/bioscirep/ article/40/7/BSR20200068/225782/PDGFA-gene-rs9690350polymorphism-increases.

100. Yang $\mathrm{Y}$, et al. MicroRNA-29b/142-5p contribute to the pathogenesis of biliary atresia by regulating the IFN- $\gamma$ gene. Cell death \& disease. 2018; 9 (5): 1-9.

101. Ye $Y$, et al. Downregulation of microRNA-145 may contribute to liver fibrosis in biliary atresia by targeting ADD3. PloS one. 2017; 12 (9): e0180896. 